\title{
Editorial
}

\section{Does the Caenorhabditis elegans protein CED-4 contain a region of homology to the mammalian death effector domain?}

\author{
Marcus E. Peter ${ }^{1,2}$, Jan Paul Medema ${ }^{1}$ and \\ Peter H. Krammer ${ }^{1}$ \\ 1 Tumor Immunology Program, German Cancer Research Center, Im \\ Neuenheimer Feld 280, D-69120 Heidelberg, tel: +49-6221-423765; \\ Fax: +49-6221-411715; E-mail: M.Peter@dkfz-heidelberg.de \\ 2 Corresponding author: Marcus E. Peter
}

Received 6.6.97; revised 9.6.97; accepted 12.6.97

Edited by G. Melino

The elucidation of the apoptosis pathway in the nematode $C$. elegans has been helpful to understand apoptosis signaling pathways in higher eukaryotes. In the worm three genes ced$3,-4$ and -9 are involved in regulating the execution of apoptosis during development (Ellis et al, 1991). Ced-3 codes for a protease homologous to the caspase family. CED-3 activity is negatively regulated by CED- 9 which is homologous both structurally and functionally to Bcl-2 and other Bcl-2 family members (Hengartner et al, 1992) such as Bcl- $\mathrm{X}_{\mathrm{L}}$. To exert its function CED-9 requires the presence of CED-4, another apoptosis promoting factor (Shaham and Horvitz, 1996). A mammalian CED-4 homolog has not been identified yet. Several reports showed that the CED-3 homolog CPP32/ caspase 3 and other CPP32-like caspases act downstream of the CED-9 homolog Bcl-2 (Chinnaiyan et al, 1996; Armstrong et al, 1996; Shimizu et al, 1996; Perry et al, 1997; Estoppey et al, 1997). In analogy to the sequence of interactions in $C$. elegans the mammalian CED-4 homolog would then be expected to act in between Bcl-2 and a CPP32-like caspase. This scenario got more complex with the identification of another member of the CPP32-like caspases, FLICE/Mach/ Mch5/caspase-8 (Muzio et al, 1996; Boldin et al, 1996; Fernandes-Alnemri et al, 1996), that couples directly to the activated CD95 receptor through binding to FADD/MORT1 (Muzio et al, 1996; Boldin et al, 1996). Could CED-4 act upstream of FLICE, the most receptor-proximal caspase?

Nagata (1996) published a homology between the first FLICE death effector domain (DED) and CED-4 placing the region of weak homology into the CED-4 C-terminus. Recently, another homology alignment between the DED of FLICE with the N-terminus of CED-4 was published (Bauer et al, 1997). Regardless of the location of the putative homology box with the DED in CED-4 these data stimulated the idea that the N-terminus of FLICE either functionally played the role of CED-4 in the mammalian system or directly bound mammalian CED-4.

Recently, a number of reports demonstrated that CED-9 can physically interact with CED-4 (Spector et al, 1997; Wu et al, 1997; Chinnaiyan et al, 1997; Ottilie et al, 1997). This interaction was also found using the mammalian CED-9 homolog Bcl- $x_{\mathrm{L}}$. In addition, Chinnaiyan et al (1997) provided a molecular framework involving a physical association of CED-4 with ICE or FLICE. The authors presented evidence that $\mathrm{Bcl}-\mathrm{x}_{\mathrm{L}}$ could physically interact with FLICE. This interaction was indirect and required the presence of a cellular protein $\mathrm{x}$, assumed to be a mammalian CED-4 homolog. We have recently shown that CD95 apoptosis resistance in peripheral $\mathrm{T}$ cell populations is characterized by a lack of FLICE recruitment into the CD95 death-inducing signaling complex (DISC) and upregulation of $\mathrm{Bcl}-\mathrm{x}_{\mathrm{L}}$ (Peter et al, 1997). Taking together all data, $\mathrm{Bcl}-\mathrm{x}_{\mathrm{L}}$ might directly regulate FLICE activity through binding to the FLICE-N-terminus. This would be in line with the order of events in $C$. elegans. Experiments based on this assumption were in part provoked by the weak homology reported between the FLICE-N-terminus and CED-4. Recent data from our laboratory and a number of inconsistencies now prompt us to put this model in doubt:

1. Association between $\mathrm{BCl}-\mathrm{X}_{\mathrm{L}}$ and FLICE was also found with ICE (Chinnaiyan et al, 1997). Since ICE does not contain a DED it is unlikely that the DED structure is required for CED-4 binding. In addition, association with CED-4 required either the $\mathrm{N}$-terminal or the $\mathrm{C}$ terminal part of ICE or FLICE. This also does not support the idea of the presence of a specific DEDrelated binding motif in both caspases.

2. Golstein (1997) has suggested that the CED-9 homolog $\mathrm{BCl}-\mathrm{X}_{\mathrm{L}}$ plays a fundamental role by interfering with the CED-3 homolog FLICE while bound to mitochondria. If this were the case this effect should be most pronounced in CD95-mediated apoptosis, in which FLICE plays an essential role.

Recently, we have described the mechanism of FLICE activation in CD95-mediated apoptosis (Medema et al, 1997a). Activation of FLICE depends exclusively on recruitment to the CD95 receptor. Therefore, if CED-4 would play a role in the activation of FLICE this would have to occur within the DISC and not at the mitochondria. A mammalian CED-4 homolog would then be expected to be part of the DISC. Furthermore, since Bcl-X/CED-9 was shown to directly interact with CED-4, it might also directly bind to the DISC thereby inhibiting the activation of FLICE. To experimentally test this possibility we looked for a cell line that was rendered resistant to CD95-mediated apoptosis by 


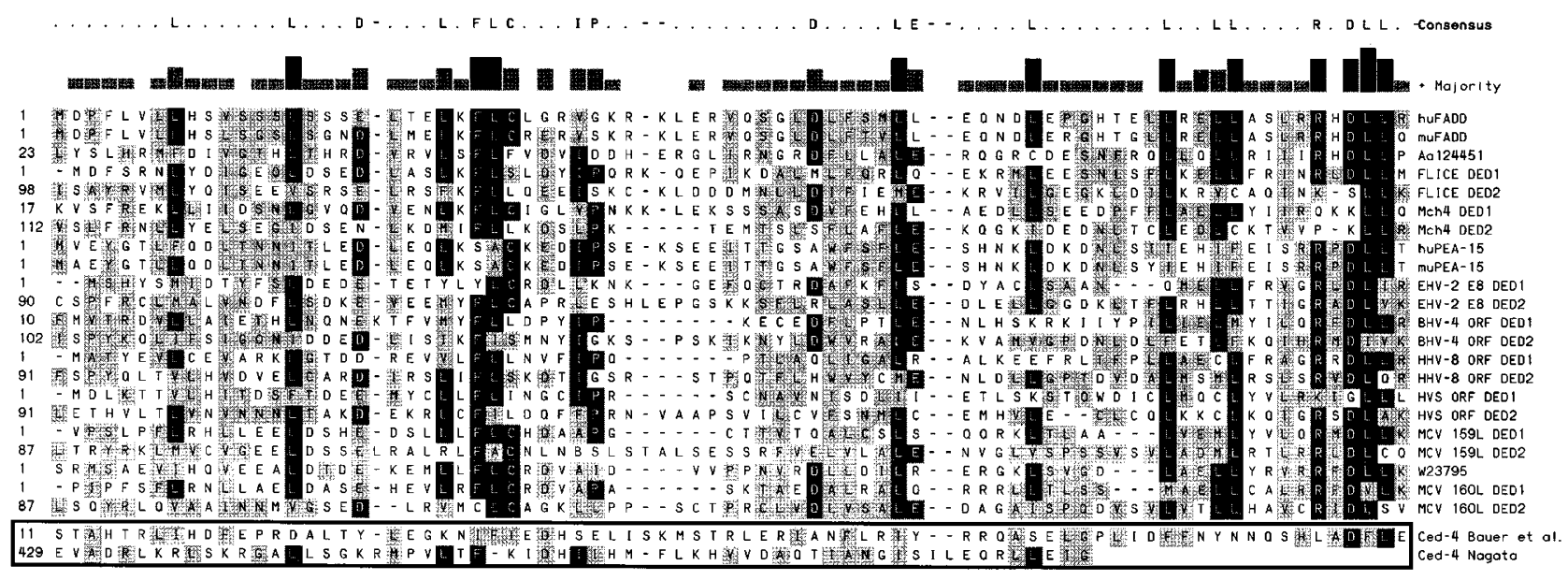

Figure 1 Alignment of known death effector domain (DED) structures (Thome et al, 1997) including two published CED-4/death effector domain homology regions and the murine proteins FADD (GenBank accession number: U43184) and PEA-15 (GenBank accession number: X86694). Black boxes indicate $\geqslant 50 \%$ identity and grey boxes indicate $\geqslant 50 \%$ sequence similarity by conserved amino acids replacements. In addition two new putative DED containing proteins are shown (GenBank Accession numbers: Aa124451 and W23795). The two putative CED4 DED regions (Nagata, 1996; Bauer et al, 1997) are boxed

overexpression of $\mathrm{Bcl}-2$ or $\mathrm{Bcl}-\mathrm{x}_{\mathrm{L}}$. However, in most reports this does not substantially affect CD95 apoptosis sensitivity (Strasser et al, 1995, Itoh et al, 1993; Martin et al, 1995; Enari et al, 1995; Memon et al, 1995; Huang et al, 1997). Some reports even placed the action of $\mathrm{Bcl}-2 / \mathrm{Bcl}-\mathrm{x}_{\mathrm{L}}$ in an apoptosis pathway parallel to the CD95 pathway (Chinnaiyan et al, 1996; Strasser et al, 1995). One of the few cell lines in which overexpression of $\mathrm{Bcl}-2$ or $\mathrm{Bcl}-\mathrm{x}_{\mathrm{L}}$ significantly delays CD95-mediated apoptosis are MCF7-Fas cells (Jäättelä et al, 1995). Testing the MCF7-Fas cells we found that overexpression of $\mathrm{Bcl}-\mathrm{x}_{\mathrm{L}}$ in these cells did not affect FLICE recruitment to the DISC or its activation (Medema et $a l, 1997 b)$. Since it was published that $B c l-x_{L}$ could be coimmunoprecipitated with FLICE when transiently transfected into 293T cells (Chinnaiyan et al, 1997) we tested whether $\mathrm{BCl}-\mathrm{x}_{\mathrm{L}} / \mathrm{FLICE}$ association could be found in MCF7Fas cells stably expressing $\mathrm{Bcl}-\mathrm{x}_{\mathrm{L}}$. Using either antibodies against $\mathrm{Bcl}-\mathrm{x}_{\mathrm{L}}$ or a set of monoclonal antibodies against different domains of FLICE we did not detect any association of $\mathrm{Bcl}-\mathrm{x}_{\mathrm{L}}$ with FLICE or its active subunits in these cells (unpublished observations). In addition we did also not find any binding or functional inhibition of the active FLICE subunits $\mathrm{p} 18 / \mathrm{p} 10$ by $\mathrm{Bcl}-\mathrm{x}_{\mathrm{L}}$. Taken together this makes it difficult to place the action of CED-4 upstream of FLICE.

3. Both published alignments between CED-4 and the mammalian DED, one placing the homology box at the CED-4 C-terminus (Nagata, 1996), the other at its Nterminus (Bauer et al, 1997) were based on the rather limited number of sequences of FLICE, FADD and PEA-15, a phosphoprotein of as yet unknown function found in astrocytes (Muzio et al, 1996). Thome et al recently reported the identification of a new class of viral FLICE inhibitory proteins (v-FLIPs) that are characterized by the presence of two DED (Thome et al, 1997). In this paper we demonstrated that these proteins both functionally and physically interact with FLICE and the DISC confirming that the search algorithm used identified functional DED containing proteins. Using this algorithm two new DED containing proteins were identified (Figure 1). One of these proteins (Accession number: W23795) shares 41\% identify on the amino acid level within the DED1 of the MCV $160 \mathrm{~L}$ and might therefore represent a human homolog of v-FLIP. Using this extended list of known DED motifs the CED-4/DED homology can be put to the test (Figure 1). Comparison of 22 different DED reveals the main conserved amino acid positions. Compared to this alignment the region in the CED-4 $\mathrm{N}$-terminus published to be homologous to the DED region by Bauer et al (1997) does not contain these key residues. In addition the alignment by Nagata (1996) involving the C-terminus of CED-4 does not cover the complete motif.

This analysis demonstrates the pitfall to only rely on a weak homology without functional data to substantiate it. Even the availability of such functional data does not guarantee the significance of an alignment. This is exemplified by the apoptosis-inducing Drosophila protein reaper (White et al, 1994). Reaper was suggested to contain a death domain (DD) by sequence alignment with the CD95and TNF-RI-DD (Golstein, 1995). However, mutagenesis of reaper and functional experiments in both mammalian and insect cells demonstrated that the essential amino acid positions found at the N-terminus of the TNF-RI DD could be replaced in reaper without affecting its cytotoxic activity (Chen et al, 1996; Vucic et al, 1997). In addition, a reaper DD structure is inconsistent with the NMR structure of the CD95 DD as reported and pointed out by Huang et al (1996). The situation with the CED-4/DED homology seems to be similar. Taking together all arguments, it is unlikely that CED-4 contains a motif structurally homologous to the mammalian death effector domain. Thus, the CED-9 homolog Bcl- $x_{L}$ seems to act downstream of FLICE and CED-4 might have a different function than binding to DED containing proteins. 


\section{References}

Amstrong RC, Aja T, Xiang J, Gaur S, Krebs JF, Hoang K, Bai X, Korsmeyer SJ, Karanewsky DS, Fritz LC and Tomaselli KJ (1996) Fas-induced activation of the cell death-related protease CPP32 is inhibited by Bcl-2 and by ICE family protease inhibitors. J. Biol. Chem. 271: 16850-16855

Bauer MKA, Wesselborg S and Schulze-Osthoff K (1997) The Caenorhabditis elegans death protein Ced-4 contains a motif with similarity to the mammalian 'death effector domain'. FEBS Lett. 402: 256-258

Boldin MP, Goncharov TM, Goltsev YV and Wallach D (1996) Involvement of MACH a novel MORT1/FADD-interacting protease, in Fas/APO-1- and TNF receptorinduced cell death. Cell 85: 803-815

Chen P, Lee P, Otto R and Abrams J (1996) Apoptotic activity of REAPER is distinct from signaling by the tumor necrosis factor receptor 1 death domain. J. Biol. Chem. 271: 25735-25737

Chinnaiyan AM, Orth K, O'Rourke K, Duan H, Poirer GG, Dixit VM (1996) Molecular ordering of the cell death pathway. Bcl-2 and $\mathrm{Bcl}-\mathrm{xL}$ function upstream of the CED-3-like apoptotic proteases. J. Biol. Chem. 271: 4573-4576

Chinnaiyan AM, O'Rourke K, Lane BR and Dixit VM (1997) Interaction of CED-4 with CED-3 and CED-9: a molecular framework for cell death. Science 275: 1122 1126

Ellis RE, Yuan J and Horvitz HR (1991) Mechanisms and functions of cell death. Annu. Rev. Cell Biol. 7: 663-698

Enari M, Hase A and Nagata S (1995) Apoptosis by a cytosolic extract from Fasactivated cells. EMBO J. 14:5201-5208

Estoppey S, Rodriguez I, Sadou R and Martinou J-C (1997) Bcl-2 prevents activation of CPP32 cysteine protease and cleavage of poly (ADP-ribose) polymerase and U1 -70 kD proteins in staurosporine-mediated apoptosis. Cell Death Differ. 4: $34-38$

Fernandes-Alnemri T, Armstrong RC, Krebs J, Srinivasula SM, Wang L, Bullrich F, Fritz LC, Trapani JA, Tomaselli KJ, Litwack G, Alnemri ES (1996) In vitro activation of CPP32 and Mch3 by Mch4, a novel human apoptotic cysteine protease containing two FADD-like domains. Proc. Natl. Acad. Sci. USA 93: $7464-7469$

Golstein P (1995) Homology between reaper and the cell death domains of Fas and TNFR1. Cell 81: $185-186$

Golstein P (1997) Controlling cell death. Science 275: 1081

Hengartner MO, Ellis RE and Horvitz HR (1992) Caenorhabditis elegans gene ced-9 protects cells from programmed cell death. Nature 356: 494-499

Huang B, Eberstadt M, Olejniczak ET, Meadows RP and Fesik SW (1996) NMR structure and mutagenesis of the Fas (APO-1/CD95) death domain. Nature 384 $638-641$

Huang DCS, Cory S and Strasser A (1997) Bcl-2, Bcl-x(L) and adenovirus protein E1B19 kD are functionally equivalent in their ability to inhibit cell death. Oncogene 14: 405-414

Itoh N, Tsujimoto Y and Nagata S (1993) Effect of bcl-2 on Fas antigen-mediated cell death. J. Immunol. 151: $621-627$

Jäättelä M, Benedict M, Tewari M, Shayman JA and Dixit VM (1995) Bcl-x and Bcl-2 inhibit TNF and Fas-induced apoptosis and activation of phospholipase A2 in breast carcinoma cells. Oncogene 10: 2297-2305
Martin SJ, Newmeyer DD, Mathias S, Farschon DM, Wang HG, Reed JC, Kolesnick RN and Green DR (1995) Cell-free reconstitution of Fas-, UV radiation- and ceramide-induced apoptosis. EMBO J. 14: 5191-5200

Medema JP, Scaffidi C, KischkelFC, Shevchenko A, Mann M, KrammerPH and Peter ME (1997a) FLICE is activated by association with the CD95 death-inducing signaling complex (DISC). EMBO J. 16: 2794-2804

Memon SA, Moreno MB, Petrak D and Zacharchuk CM (1995) Bcl-2 blocks glucocorticoid-butnotFas-or activation-induced apoptosis in a T cell hybridoma. J. Immunol. 155: 4644-4652

Muzio M, Chinnaiyan AM, Kischkel FC, O'Rourke K, Shevchenko A, Ni J, Scaffidi C Bretz JD, Zhang M, Gentz R, Mann M, Krammer PH, Peter ME and Dixit VM (1996) FLICE, a novel FADD-homologous ICE/CED-3-like protease, is recruited to the CD95 (Fas/APO-1) death-inducing signaling complex. Cell 85: 817-827

Nagata S (1996) Apoptosis: telling cells their time is up. Curr. Biology 6: 1241-1243

Ottilie S, Wang Y, Banks S, Chang J, Vigna NJ, Weeks S, Armstrong RC, Fritz LC and Oltersdorf T (1997) Mutational analysis of the interacting cell death regulators CED-9 and CED-4. Cell Death Differ. 4:526-533

Peter ME, Kischkel FC, Scheuerpflug CG, Medema JP, Debatin K-M and Krammer $\mathrm{PH}$ (1997) Resistance of cultured peripheral T cells towards activation-induced cell death involves a lack of recruitment of FLICE (MACH/caspase-8) to the CD95 death-inducing signaling complex. Eur. J. Immunol. 27: 1207-1212

Perry DK, Smyth MJ, Wang H-G, Reed JC, Duriez P, Poirier GG, Obeid LM and Hannun YA (1997) Bcl-2 acts upstream of the PARP protease and prevents its activation. Cell Death Differ. 4: 29-33

Shaham S and Horvitz HR (1996) Developing Caenorhabditis elegans neurons may contain both cell-death protective and killer activities. Genes Dev. 10: 578-591

Shimizu S, EguchiY, KamiikeW, Matsuda Hand Tsujimoto Y (1996) Bcl-2 expression prevents activation of the ICE protease cascade. Oncogene 12: 2251-2257

Spector MS, Desnoyers S, Hoeppner DJ and Hengartner MO (1997) Interaction between the C-elegans cell-death regulators CED-9 and CED-4. Nature 385: $653-656$

Strasser A, Harris AW, Huang DCS, Krammer PH and Cory S (1995) Bcl-2 and Fas/ APO-1 regulate distinct pathways to lymphocyte apoptosis. EMBO J. 14:61366147

Thome M, Schneider P, Hofmann K, Fickenscher H, Mein IE, Neipel F, Mattmann C, Burns K, Bodmer JL, Schroter M, Scaffidi C, Krammer PH, Peter ME and Tschopp J (1997) Viral FLICE-inhibitory proteins (FLIPs) prevent apoptosis induced by death receptors. Nature 386: 517-521

Vucic D, Seshagiri S and Miller LK (1997) Characterization of reaper- and FADDinduced apoptosis in a lepidopteran cell line. Mol. Cell. Biol. 17: 667-676

White K, Grether ME, Abrams JM, Young L, Farrell K and Steller H (1994) Genetic control of programmed cell death in Drosophila. Science 264: 677-683

Wu DY, Wallen HD and Nuñez G (1997) Interaction and regulation of subcellular localization of CED-4 by CED-9. Science 275: 1126-1129 